\title{
Analysis on Environmental Pollution of MNEs from the Perspective of the Host Country, China
}

\author{
Sizhe $\mathrm{Liu}^{1, \mathrm{a}, *, \dagger}$, Weiwen Qian ${ }^{2,{ }^{*}, \dagger}$, Peike $\mathrm{Wu}^{3, \mathrm{c}, * \dagger}$ \\ ${ }^{1}$ Queen's University, Kingston, Ontario, Canada \\ ${ }^{2}$ The Franklin Thomas Backus School of Law, Case Western Reserve University, Cleveland, Ohio, USA \\ ${ }^{3}$ School of Management and Economic, The Chinese University of Hongkong (Shenzhen), Guangdong, China \\ *Email:. ${ }^{*} 17 s 191 @ q u e e n s u . c a,{ }^{b} 376482167 @ q q . c o m,{ }^{c}$ peikewu@link.cuhk.edu.cn
}

${ }^{t}$ These authors contributed equally to this paper.

\begin{abstract}
The investment of multinational enterprises (hereinafter referred to as MNEs) in China has promoted the local economy's development and caused serious environmental damage. From the perspective of MNEs, the reason is the high cost of environmental protection in the home country of MNEs leads to the internalization of the environmental cost and the absence of the principle of public interest in the enterprise value orientation. From the perspective of the host country, the reason is the development philosophy of Economy Polarism. Taking China as an example, this paper summarizes three main forms of damage to the environment caused by multinational enterprises and analyze the existing problems of the current legal system. Based on what has been mentioned above, the following suggestions are given: to improve the law related to the environmental problem, reinforce the supervision for the MNEs and increase the punishment of pollution.
\end{abstract}

Keywords: MNEs, Host country, Environmental damage, China, Legal provision.

\section{INTRODUCTION}

At the early stage of the Economic Reform and Open up, the economic circle believed that the 'Pollution Halo' would appear when China introduced international investment. The 'Pollution Halo' hypothesis considers that if the MNEs with advanced management experience and environmental technology are allowed into China, they will bring the advanced environmental protection technology to china and leading to technology upgrading of local enterprises through technology spillover effect [1]. At the same time, local enterprises will take the initiative to eliminate backward polluting industries to realize the economic theories of Pareto Optimality. However, decades of development have proved that the hypothesis is an idealized conjecture. Although the investment of MNEs in China has promoted the development of the local economy, it has also caused serious environmental damage. There are two reasons for this result. On the one hand, the high cost of environmental protection in the home country of MNEs leads to the internalization of environmental cost [2] and the absence of the principle of public interest in the enterprise value orientation. According to the externality theory, the Pareto Optimality solution formed by internalizing the externality problem will cause the firm to suffer certain economic losses [3]. In other words, the internalization of environmental costs will inevitably damage the economic interests of enterprises. Therefore, when the intensity of environmental supervision is weak, MNEs often choose to replace the high cost of pollution control and the capital expenditure of environmental protection brought by internalization with the environmental tax or penalty, which is less costly after the pollution discharge. For example, suppose a multinational enterprise's home country has complete and strict environmental standards. In that case, it will transfer industries prone to environmental damage to developing countries with relatively low environmental protection standards through international investment to avoid the high cost of environmental protection caused by the high environmental standards of their home countries and internalization of environmental protection cost. In addition, due to the absence of the principle of public interest in the value orientation of some MNEs, leading 
to the lack of due respect for the legitimate rights and interests of the host country. As a result, as soon as these law-abiding MNEs in their home countries have completed the industrial transfer, they began to discharge pollution and damage the local environment in host countries.

On the other hand, from the host country's perspective, the low environmental standards are due to the development philosophy of Economic Polarism. Economy Polarism refers to the pursuit of economic interests as the sole purpose and power of development. It belongs to economic materialism [4]. Take China as an example. China's urgent demand for economic development in the early stage of Economic Reform and Open up led to its low environmental access threshold. From the perspective of economic development, international investment can indeed bring a variety of benefits to the host country, such as economic development, transfer of science and technology, increased jobs, and so on. Therefore, in the early stage of Economic Reform and Open up, China set low environmental access standards and implemented low supervision to attract international investment, which led to many industries that could easily cause environmental damage entering China. Additionally, some local governments in less developed areas also follow the development philosophy of Economic Polarism and take the initiative to lower the review threshold and force of supervision of environmental pollution for short-term economic benefits. Consequently, when there is a conflict between economic interests and environmental protection, these local governments will often choose between sacrificing the environment to protect economic interests, making local governments the refuge for MNEs to trade pollution for profits.

At present, there are three main forms of damage to China's environment caused by MNEs. First, pollution emissions. In the early years of China's Economic Reform and Open up in the 1990s, international investment poured in, even though China had not yet set up pollution standards. As MNEs mainly relied on coal, oil, and other low-cost polluting energy in production and operation, a large number of gaseous pollutants such as sulfur dioxide were directly discharged. Meanwhile, industrial wastewater (waste liquid) and other liquid pollutants were also directly discharged into rivers and lakes, causing serious local air and water pollution. In addition, there is also soil pollution caused by the random disposal of solid waste by MNEs. Second, predatory exploitation of natural resources. China's abundant natural resources are one of the important factors attracting MNEs to invest in China. However, while some MNEs exploit China's natural resources, they are unwilling to undertake the obligation of environmental protection, which leads to the serious damage of China's natural environment. Although China restricts international investment in exploration and development of rare metals and fishing through Special Administrative Measures (Negative List) for Foreign Investment Access, it imposes relatively loose restrictions on international investment from the perspective of natural resource protection. This lack of system enables MNEs to carry out predatory development with the acquiescence of local governments as long as they do not violate the system bottom line stipulated by the Chinese government, thus causing irreparable damage to the local ecological environment. Third, use China as a waste disposal center. MNEs export waste to China by paying high waste disposal fees. China gets high waste treatment fees and cheap raw materials from the waste. For developed countries with higher labor costs, such recycling is unprofitable. Still, China relies on a large number of cheap labor brought by the demographic dividend, established the mode of garbage sorting and recycling coordinated by manpower and machinery. Nevertheless, this model has many disadvantages. First of all, most of the garbage can only be stored in the open garbage dumps, and the long-term stacking pollutes the water and soil around the dumps. Secondly, practitioners have been exposed to harmful gases such as ammonia and sulfide released from garbage for a long time, which may cause damage to their health that is difficult to recover. Finally, the non-recyclable garbage can only be destroyed by centralized incineration, which seriously damages the surrounding air quality. In summary, the paper takes the environmental damage caused by MNEs to China as the entry point, cites the current laws and regulations and relevant cases, analyzes and studies the defects of China's current environmental supervision system for foreign investment, and proposes corresponding governance measures on this basis.

\section{PROBLEMS OBSERVED}

\subsection{The current environmental management mechanism}

The market access of MNEs in China is subjected to the Foreign Investment Law of the People's Republic of China (hereinafter referred to as Foreign Investment Law) and the Negative List of Foreign Access (hereinafter referred to as Negative List). The Foreign Investment Law clearly stipulates that "The access of multinational companies should refer to the Negative List. Apart from companies that belong to the 'restricted' or 'prohibited' categories, the entry of other companies should follow national treatments"[5]. There are no explicit auditing measures for companies that may cause ecological damage or environmental pollution in the latest Negative List. However, in the 2015 Negative List (Draft for Comment), it is clearly stated that strict control will be taken on ecological protection, which 
shows that environmental protection has gradually attracted the attention of the Chinese government.

China mainly regulates the environmental problems of MNEs according to Environmental Protection Law, Water Pollution Law, Air Pollution Law, and Solid Waste Management Law. A relatively complete environmental management mechanism has been formed under the framework of Environmental Protection Law. This kind of management mechanism includes the precautionary system with environmental protection planning, project environmental assessment, environmental carrying capacity monitoring, and early warning mechanism. It also includes an in-process supervision system with environmental monitoring system, a "three simultaneities" system, sewage charge (tax) system, and total amount control system, as well as the post-compensation system for ecological restoration and the liability insurance system for environmental pollution [6].

Among them, the precautionary system plays a very important role. Within this system, the environmental impact assessment system is the most mature system at present. China introduced the environmental impact assessment system in 1973. In 2003, a special environmental impact assessment law was formally implemented. It is an important part of the precautionary system, which plays a key role in the process of environmental access of MNEs. However, compared with other developed countries, there are still many limitations in the specific operation of environmental impact assessment in China. Such as the lack of effective public participation in the environmental impact process, the low degree of enterprise information disclosure, and so on. These limitations decrease the restricting the access of enterprises related to environmental pollution, increasing the burden of follow-up management and increasing the possible environmental costs.

In addition, as far as the post-compensation system is concerned, the biggest problem in our country is the lack of guiding cases for reference in judicial practice. The Supreme people`s Court of The People`s Republic of China (hereinafter referred to as The Supreme Court) has issued a total of 26 batches of 147 guiding cases (No.9 and No.20 guiding cases are no longer applicable from January 1, 2021). Of the 147 guiding cases, only 13 are related to environmental protection, accounting for a relatively small proportion in the overall case. At the same time, the release time of these cases is relatively late-most of them were released in 2020. And it does not include related cases involving environmental infringement of MNEs. The promulgation of guiding cases reflects that environmental protection issues have gradually gained the attention of our judicial organs. It also provides trial guidance for similar cases in the future. However, compared with the normal law countries with earlier promulgation and perfect system, there is still much room for improvement in guiding cases in China.

\subsection{The liability distribution between parent and subsidiary companies}

In June 2011, an oil spill occurred in Penglai 19-3 Oilfield. After the incident, ConocoPhillips China Co., Ltd. (hereinafter referred to as ConocoPhillips China) attempted to conceal and cover up the pollution facts caused by itself by taking measures to delay false reporting. It led to expanding the oil pollution area along the coast of Laoting County from the original 840 square kilometers to 6,200 square kilometers. It has caused direct losses of hundreds of millions of yuan to coastal aquaculture in Laoting County. This oil spill has had a huge impact on coastal residents' lives and caused huge losses to aquaculture and other related industries around the Bohai Sea and even brought irreparable losses to the ecosystem of the Bohai Sea. Two months after the accident, the Beihai Branch of the State Oceanic Administration of China filed a public interest lawsuit for damages against the party responsible for the accident on behalf of the state. However, it was not until April 2014 that the State Oceanic Administration announced that ConocoPhillips China Limited and China National Offshore Oil Corporation had paid a total of 1.683 billion yuan for the accident. The operator who caused the accident was ConocoPhillips China. It is a wholly-owned subsidiary of ConocoPhillips. However, for this compensation, the parent company ConocoPhillips only contributed 1.09 billion yuan.

It can be seen from this that the compensation work for this incident is not going smoothly in terms of time. We can see that it is still difficult for a country's government department to claim compensation for large multinational parent-subsidiary companies that cause serious pollution. In addition, the regulations on how parent-subsidiary companies bear legal responsibilities are not perfect. It is a long way to ask the parent company and the subsidiary company to jointly bear the civil liability for compensation in environmental infringement. It is worth noting that in this case, ConocoPhillips, as the parent company, has assumed the corresponding liability for compensation for the environmental pollution caused by its wholly-owned subsidiary. From the results of this liability, we can easily find that if the improper behavior of the company causes the environmental pollution. The parent company can't take any responsibility on the grounds of limited liability or independent legal personality. Instead, it should assume the corporate social responsibility that MNEs should have. However, in practice, the existing laws do not clearly stipulate how to shoulder the responsibility of environmental protection jointly by the parent company and investigate the parent company's 
responsibility. At present, only Article 5 of Company Law and Article 9 of Civil Code stipulate that companies should bear corresponding social responsibilities. However, the above provisions do not specify the specific content and responsibility of social responsibility. It is only a principle provision, which is not operable in judicial practice [7].

Some scholars argue that the system of denial of legal personality can be invoked in view of environmental tort liability determination. That is, although the company has an independent legal personality and can bear civil liability independently when the improper behavior of its subsidiary causes environmental damage, it should not only pursue the liability of its subsidiary under any circumstances [8]. Especially when the subsidiary company is unable to bear the responsibility or the personality of the parent company is confused. The system of denying the personality of a legal person should be invoked at this time, and the parent company should be included in the scope of liability subject to tort damages. For example, after the pollution incident occurred in Xinyi Zijin Mining, the plaintiff claimed that Xinyi Zijin was confused with Zijin Group in property, personnel, business, and other aspects. The legal person of Xinyi Zijin Company had no independent personality right. Therefore, Zijin Group should be listed as a codefendant, and Zijin Group should be jointly and severally liable for compensation. Limited liability can't be an excuse for the company to harm public interests. In the environmental pollution incidents of MNEs, it is necessary to identify the situations in which the parent and subsidiary companies apply or inappropriately apply personality denial to find the best balance between safeguarding the interests of MNEs and environmental protection. Because the company operation is an extremely complicated process, especially when MNEs set up subsidiaries in the host country, their relationship is more complicated. Although the subsidiary is independent according to the law, the parent company and the subsidiary will inevitably have business contacts, personnel flow, resource sharing, etc. Therefore, it is very important to judge whether there is a confusion of corporate personality between parent and subsidiary companies in the case of environmental infringement. According to the relevant provisions of Article 20 of the Company Law, when the shareholders of the company abuse their rights and cause damage, they should compensate the creditors of the company. Then when the parent company, as a shareholder of the subsidiary, abuses its power and causes environmental infringement of the subsidiary, the parent should bear the liability for compensation. However, this article only stipulates those creditors have the right to exercise the system of denial of legal personality but does not provide for other subjects. In other words, the subject scope of the corporate personality ignorance system in China's company law is narrow. It is difficult to apply the denial of corporate personality to environmental pollution, which harms public interests.

\subsection{The number of punitive damages}

From the introduction of the punitive damages system in Consumer Protection Law to establishing a punitive damages system in ecological environment infringement in the Civil Code, the legislative evolution of punitive damages shows that. The punitive damages system of ecological, environmental infringement is a system that grafts the strictness of public law in regulating environmental violations and the flexibility of private law in enforcing laws. It is close to civil liability in form and similar to administrative liability or criminal liability in nature.

At present, in China's judicial practice, the subjective elements of the punitive damages system for infringement of ecological environment are still limited to the category of "intention", which excludes the application of "gross negligence"[9]. In addition, countries different from the common law system need to consider many factors when determining punitive damages. When determining the number of punitive damages in China, we mainly consider the actual damages. According to the Product Liability Law and the Food Safety Law provisions, punitive damages are determined because the victim suffers actual losses or pays the price. Therefore, the main consideration is the actual damage suffered by the victim. In practice, the premise of advocating punitive damages is that environmental tort has caused serious personal injury, property damage, and ecological environment damage. Among them, the determination of punitive damages for ecological, environmental damage, its base is mainly the loss of service function and the loss caused by permanent damage of ecological environment function during ecological environment restoration. In addition, to properly coordinate the relationship between environmental protection and economic development, and at the same time, to ensure a reasonable proportion between compensatory damages and punitive damages, China has limited the maximum amount of punitive damages. The above legal provisions seem reasonable. However, in practice, MNEs frequently violate our environment because the amount of compensation for environmental damage in China is far lower than the regulations of their home countries. Therefore, China must redefine the punitive damages system for environmental damage.

\section{SUGGESTIONS}




\subsection{Improving the legal provisions on the environmental responsibility of MNEs in China}

As mentioned above, on the one hand, China lacks the guiding case about environmental protection. But, on the other hand, there is still a gap between the environmental standards and the current international mainstream standards. This is one of the reasons why MNEs take the opportunity to create environmental problems in China. Therefore, China should clearly formulate the environmental liability of MNEs in China, intensifying the punitive measures of illegal discharge of pollutants, perfecting the construction of an environmental tax system, and supplementing the liability of MNEs for pollution in China.

First of all, we should clarify the environmental responsibility of MNEs in China. When signing investment agreements related to international trade with the home countries of MNEs, necessary environmental provisions shall be added. For example, the behavior of MNEs in China must meet certain environmental standards. Otherwise, they will be punished accordingly. Secondly, we should improve the environmental legal system of our country, keeping the emission standards of pollutants consistent with the international mainstream ISO140000 environmental standards and stipulating the corresponding punishment measures. Finally, MNEs must strictly abide by China's environmental protection standards and requirements and earnestly fulfill the corresponding environmental obligations. It is worth noting that when MNEs in special industries enter China, such as the chemical industry, MNEs and the government of the place where they invest can be required to sign a guarantee with the same environmental standards and responsibilities as their home country.

At present, China lacks a complete system of the environmental taxation system. The development of the environmental tax system in developed countries is quite mature. The practical experience and theoretical research of OECD countries show that establishing an environmental tax system can effectively reduce the environmental pollution caused by MNEs in host countries[10]. Therefore, China can take environmental protection as the core and learn from the beneficial experience of developed countries to improve China's environmental tax system. Specifically, from the scope of taxpayers, we can set taxpayers as MNEs that develop and use environmental resources and cause environmental pollution. From the perspective of expropriation scope, non-renewable resources, rare resources, and polluting behaviors in production are the main ones. Tax incentives can be implemented for effective pollution control and clean production from the perspective of tax incentives.
Companies' environmental standards and requirements in developed countries are relatively high, and a special environmental information disclosure system is formulated. MNEs in the motherland's operations generally strictly abide by the relevant environmental responsibility standards of the motherland and strictly disclose the environmental information of the enterprise. However, since my country's environmental protection legal system is not perfect, MNEs' subsidiaries often take trade secrets excuses to refuse to undertake this obligation. Therefore, from the perspective of preventing MNEs to make damages to our country, to contain environmental pollution behaviors, the environmental information disclosure system should be improved, and the disclosed content, method, evaluation criteria, etc. The detailed and specific standards should be stipulated to ensure the operability of the system. Public information is disclosed as an important legal obligation of MNEs while strengthening the transparency of MNEs in my country's performance responsibility. The system not only requires a subsidiary of MNEs to fulfill this obligation, considering the relationship between the parent company and subsidiary. The subsidiary's business activities and business scope are generally held and decided by the parent company, so the parent company of MNEs must provide necessary cooperation and support.

When claiming accountability for MNEs, it may happen that the subsidiaries of MNEs in the host country cannot afford compensation for environmental damage. In view of this situation, it is necessary to consider the responsibility of the parent company. However, according to our country's existing laws and regulations, there is a phenomenon that it is hard to claim accountability. Some scholars have suggested that the system of denial of corporate personality in the Company Law can be introduced in the aspect of environmental damage compensation. However, in China, this system mainly prevents the company's shareholders from abusing the company's independent personality and infringing on the interests of creditors. Creditors have the right to request the court to apply this system only when the creditor's rights are not realized. In a word, the application scope of the denial of legal personality in China is narrow. The factors that need to be considered when applying the system in the United States include "damage to the public interests". In essence, environmental damage is damage to public social interests. Therefore, China should improve the Company Law and other regulations, and bring "damage to public social interests" into the system of denial of corporate personality. There can be laws to follow when the parent company is investigated for environmental damage responsibility. 


\subsection{Strengthening the supervision of MNEs' environmental pollution behaviors}

First of all, the country should try to establish an independent environmental supervision department of MNEs, which should examine whether local governments prioritize economic development at the expense of environmental damage. At ordinary times, environmental supervision departments should pay more attention to the relevant environmental protection aspects of MNEs, so that they can consciously and actively accept guidance and supervision. In addition, the environmental protection department should also pay attention to the production norms of MNEs, strengthen the adjustment of industrial structure, eliminate backward enterprises with relatively serious environmental pollution, strengthen environmental law enforcement, and create a good environment under the rule of law, to achieve the goal of implementing the supervision and enforcement of MNEs. Finally, the supervision of local governments should be strengthened to ensure that local governments strictly enforce the law. To promote the enthusiasm of local governments in law enforcement, environmental protection can be regarded as part of the achievements of local governments. Let local governments pay attention to environmental issues and earnestly implement the environmental standards of the central government.

Second, strengthen the participation of nongovernmental organizations. In recent years, nongovernmental organizations have gradually grown in the field of human rights and environmental sectors, and become an active person who maintains world peace and security. Among them, non-governmental environmental protection organizations, with their unique professionalism and influence, achieve the goal of harmonious progress between human economic development and ecological environment protection by participating in the formulation of international environmental standards, supervising the environmental impact behavior of MNEs, providing advice for the formulation of national environmental policies, and disseminating environmental protection knowledge to the public. On this basis, our country can make full use of the participation of third-party organizations and the public to monitor the environmental pollution of MNEs.

China's Constitution affirms the state's obligation to protect the environment in the form of a basic national policy. The academic theory of a country ruled by law generally holds that the state's obligation originates from the basic rights of citizens and arises at the request of the basic rights of citizens, to safeguard the basic rights of citizens. Therefore, the basic right of citizens to enjoy environmental rights contains the legal basis behind the constitutional provisions [11]. The "environmental right" is universally recognized. Every citizen has the right to protect his living environment from any country or individual, providing a legal basis for natural persons and non-governmental organizations to exercise their supervisory power. Public participation in environmental protection activities can have positive significance for the development of environmental protection. As the direct victims of environmental pollution and the main bearers of pollution consequences, the public should play an active role in dealing with environmental pollution. Therefore, the state can't ignore the power of the public, encouraging the public to establish the awareness of environmental protection, and actively exercising their rights in the process of environmental protection. This requires the state to determine citizens' right to environmental supervision and environmental litigation in the form of law. The reason is that, on the one hand, it can stimulate the enthusiasm of public participation in environmental governance; On the other hand, it can effectively curb the behavior of MNEs ignoring environmental protection.

\subsection{Intensifying penalties for environmental pollution}

We will implement strict environmental pollution control policies, and increase penalties for MNEs, thus effectively improving the quality of the environment. From the basic connotation described by the environmental Kuznets curve, it can be seen that the developed countries have taken on the road of pollution before treatment in the process of economic development [12]. At present, China has reached the stage of governance, so the government should further increase penalties to solve the "historical problems" of environmental pollution to introduce foreign capital in the past. Environmental goods are regarded as public goods in economics, which have the characteristics of publicity and irreplaceability. Depending on the nature of public goods, the environmental quality of a country or region can hardly be improved by private investment. At the same time, the over-consumption of environmental public goods is a common problem in real life and production and the free-rider problem. Based on this, the government's strict environmental protection policy can weaken the motivation of the developed countries to transfer the highly polluting industries to China and change and optimize the trajectory of the environmental Kuznets curve. It makes the trend of environmental pollution rising in our country become flat or be restrained accordingly, to improve the environmental quality.

In short, in terms of the intensity of environmental penalties, China's existing laws and regulations stipulate that fines should be imposed according to the percentage of direct losses, up to $30 \%$ in the highest proportion. And there is a limit on the maximum 
amount of penalties for air pollution, solid waste pollution, marine environmental pollution, etc. There is an obvious gap between this and the current standard of environmental compensation in developed countries. MNEs can achieve "zero pollution" in their home country but become "major polluters" after entering China because the punishment for environmental pollution is too light. For example, in the ConocoPhillips oil spill in Bohai Bay, the damages paid by ConocoPhillips of the United States are only 1 billion yuan. This is a far cry from the US Chevron Oil Company's compensation of US $\$ 10.7$ billion to Brazil and the British BP Oil Company's compensation of more than the US $\$ 100$ billion to the United States. According to the regulations of various countries on punitive damages, the reason why punitive compensation liability is set up is to form a deterrent to the relevant subjects and make them take the initiative to take measures to reduce the risk of environmental pollution after weighing the pros and cons. Only in this way can we effectively prevent and curb the environmental pollution problems of MNEs. Therefore, China should use the provisions of punitive compensation in the Civil Code to improve the intensity of compensation for environmental damage and eliminate the limit of the maximum amount of punishment. For the environmental pollution caused by MNEs, the amount of compensation should be based on its ability to restore the environment to its original state. If it cannot be restored, it will be compensated by punitive compensation. Only by increasing the intensity of punishment can we effectively prevent the environmental pollution of MNEs.

\section{CONCLUSION}

Since the early 1990s, the wave of economic globalization gradually began to sweep the whole world. At the same time, MNEs have brought opportunities for developing countries by bringing capital, technology, and experience. However, the environmental pollution brought by MNEs to host countries have become increasingly prominent, and how to improve the environmental regulatory mechanism for MNEs has become a significant development issue for host countries. For example, in China, the current environmental regulatory mechanism lacks clear auditing measures and lacks guiding cases on environmental protection. The current regulations even lack provisions to hold the parent companies of MNEs accountable, and the number of punitive damages is much lower than that of the home countries of MNEs regulations. Based on this, this paper argues that China should clearly define the environmental liability of multinational corporations and improve the environmental taxation system. The legal personality denial system in corporate law should be introduced when pursuing the environmental damage liability of parent companies of multinational corporations. On the one hand, the supervision of environmental pollution by multinational corporations should be strengthened by establishing independent environmental supervision departments for MNEs and giving them the authority to review the law enforcement of local governments. On the other hand, the participation of NGOs should also be strengthened. Finally, the penalties for environmental pollution should be increased. If the maximum penalty amount is eliminated, the penalty standard should be based on restoring the original state; if it cannot be restored, punitive damages should be imposed based on the assessment of direct or indirect damages.

\section{REFERENCES}

[1] Jinkai Li, Liyan Cheng, Tongbin Zhang, Does the foreign direct investment have the pollution halo effect?, in: China Population, Resources and Environment, Vol. 27, 2017, pp. 74-83. DOI: CNKI:SUN:ZGRZ.0.2017-10-009.

[2] Jingyan $\mathrm{Fu}$, Internalization of Environmental Cost and Industrial International Competitiveness, China Industrial Economics, 2002, pp. 37-44. DOI:10.19581/j.cnki.ciejournal.2002.06.005.

[3] A. Mas-colell, M. Whinston, J. Green, Microeconomic Theory, Oxford University Press, 1995.

[4] Dehong Lin, Human and Machine -- Essence of High Technology and Renaissance of Humanistic Spirit, Jiangsu Education Press, 1999.

[5] "Foreign Investment Law of the People's Republic of China." China National People's Congress, 2019 ,

DOI: www.npc.gov.cn/zgrdw/npc/xinwen/201903/15/content_2083532.htm.

[6] Jing Wang, Analyze the Reform Direction of China's Project Environmental Impact Assessment System from the Comparison between China and Foreign Countries, in: Environmental Protection, 2012, pp. 71-73. DOI: 10.14026/j.cnki.02539705.2012.22.022.

[7] Xueying $\mathrm{Xu}, \mathrm{An}$ Analysis of the Social Responsibility of the Company-From the Perspective of Article 5 of Company Law, in: Business Forum, Vol. 52, 2015, pp. 187. DOI: CNKI:SUN:SHNG.0.2015-52-164.

[8] Xiaoming Lin, A.A. (2019) Research on Application of Disregard of Legal Personality of Parent and Subsidiary Company in Environmental Tort, Unpublished Masterly Dissertation, Southwest University of Political Science \& Law, Chongqin. 
[9] Xiaohan Wang, The Legal Application of the Punitive Compensation System for Ecological Environmental Infringement, in: Shandong Social Sciences, Vol. 03, 2021, pp. 169-173. DOI:10.14112/j.cnki.37-1053/c.2021.03.028.

[10] Zhiqiang Liu, Huihui Wang, On the basic theory of environmental rights as human rights, in: Human Rights Studies, Vol. 22, 2019, pp. 133-157. DOI: CNKI:SUN:RQYJ.0.2019-02-007.

[11] Chu Lan Khanh, Economic structure and environmental Kuznets curve hypothesis: new evidence from economic complexity, in: Applied Economics Letters, Vol. 28, 2021, pp. 612-616. DOI: $10.1080 / 13504851.2020 .1767280$

[12] Jiaqiang $\mathrm{Wu}$, Research on Building Green Environmental Tax System, in: Institute of Fiscal Science, Ministry of Finance, 2013. DOI: https://kns.cnki.net/kcms/detail/detail.aspx?FileNa $m e=1013333106$. nh $\&$ DbName $=$ CDFD2013 